\title{
Monetary Policy Transmission in the Euro Zone
}

\author{
By Ayla Ŏguş Binatli \\ Niloufer Sohrabji ${ }^{\dagger}$
}

\begin{abstract}
This paper focuses on monetary policy transmission through the bank lending channel in the euro zone. We analyze the relationship between output, inflation, short-term and longterm interest rates, and bank loans. In addition, based on recent concerns of rising deficits and debt we include three variables that capture fiscal vulnerability. Using quarterly data from 2002 to 2016 for the original twelve members of the euro zone (Austria, Belgium, Finland, France, Germany, Greece, Ireland, Italy, Luxembourg, Netherlands, Portugal, and Spain) we estimate a panel vector autoregression and examine impulse responses and variance decompositions. Our results show that tight monetary policy leads to an expected decline in output, but surprisingly, raises prices. We also find that the high deficits and debt burdens affect monetary policy transmission for the euro zone-12 countries. Overall, our results suggest that the euro zone is at best, only partially functioning as a cohesive unit.
\end{abstract}

Keywords: Bank Lending, Eurozone, Monetary Policy Transmission, Panel VAR.

\section{Introduction}

A significant concern for central banks is the transmission effect of monetary policy on the macro-economy such as output or unemployment. This paper analyzes monetary policy transmission for the original twelve euro zone members (Austria, Belgium, Finland, France, Germany, Greece, Ireland, Italy, Luxembourg, Netherlands, Portugal and Spain) referred to as euro zone-12. We address two main questions: How has monetary policy impacted output and inflation in the euro zone since the introduction of the euro? Do high deficits and debt burdens affect monetary policy transmission in the euro zone? Through addressing these questions we shed light on the effectiveness in monetary policy transmission since the introduction of the euro.

Monetary policy transmission has been studied for euro zone countries but our work differs from the literature in a few ways. First, we focus on the banklending channel of monetary policy transmission which has been studied significantly in the literature, but not in the context of the euro zone. Secondly, we use a panel approach to study the euro zone as a group. Finally, we add fiscal indicators to the empirical analysis to capture if, and how, monetary policy transmission is affected by countries breaching the established thresholds outlined in the Maastricht Treaty.

Using quarterly data from 2002 to 2016 for the euro zone-12 countries we estimate a panel VAR and analyze the impulse response function and the variance

${ }^{*}$ Professor, Department of Economics, Izmir University of Economics, Turkey.

${ }^{\dagger}$ Associate Professor, Department of Economics, Simmons University, USA. 
decomposition results. Our panel result shows that positive shocks to short-term interest rate lead to falling output and unexpectedly, rising prices. We also find that a "large"1 deficits and debt affect monetary policy transmission for the euro zone-12 countries. A comparative analysis of our results with earlier work leads us to conclude that euro zone is at best, only partially functioning as a cohesive unit

The paper is organized as follows: the next section provides a background on monetary policy transmission in the euro zone which is followed by a discussion of the relevant literature. The section after that provides the framework for examining monetary policy transmission which is followed by an analysis the results. The last section concludes.

\section{Monetary Policy Transmission in the Euro zone}

The monetary policy transmission mechanism seeks to identify the impact of monetary policy on output and unemployment. There are different channels of monetary policy transmission including the interest rate channel and the bank lending channel. ${ }^{2}$ In the case of the interest rate channel, monetary policy impacts the short-term interest rate which affects the long-term interest rate and finally leading to higher costs for firms and thus a decline in output (Ireland 2005). According to Angeloni et al. (2002), the interest channel is significant for European countries. Another channel is bank lending which has been emphasized by Bernanke and Blinder (1992) and Kashyap and Stein (1995) in the U.S. and Hülsewig et al. (2004) for Germany. In this view tight monetary policy which reduces bank deposits, leads to cuts in bank lending and ultimately hurts output (Ireland 2005). We do not address the debate of the relative importance of different channels in monetary policy transmission. Rather we focus on the bank lending channel which is widely studied in the literature, although, not in the context of the euro zone.

Analyzing monetary policy transmission in the euro zone is especially challenging because the European Central Bank (ECB) must coordinate policy for a heterogeneous group of countries. Even once the policy is formulated, diverse conditions in member countries can lead to differential impacts of monetary policy. In addition to economic differences, Cecchetti (1999) argues that variations in financial structures due to legal differences are another reason why euro zone countries may be affected differently by monetary policy.

The creation of a monetary union was expected to reduce this asymmetry. Angeloni and Ehrmann (2003) examine monetary policy transmission since the European Monetary Union was established by which they mean the "entire process of preparation and introduction of the single currency" (p. 6). By examining banking systems, "cross-border banking penetration" and "effect of monetary impulses on lending and deposit interest rates" (p. 7) and financial

\footnotetext{
${ }^{1}$ Large is defined using the Maastricht Treaty threshold of 3\% and 60\% for deficits and debt respectively.

${ }^{2} \mathrm{We}$ discuss two most common channels here, but there are others as well including exchange rates, asset prices, and balance sheet discussed more carefully by Ireland (2005).
} 
markets (real interest rates and equity prices) they conclude that there is some convergence in responses to monetary policy in euro zone countries since the creation of the union. We analyze the asymmetry question by estimating the monetary policy transmission since the euro was introduced in 2001.

In addition, our paper incorporates another challenge in monetary policy transmission, high deficits and debt burdens. As set up by the Maastricht Treaty, countries had to meet two fiscal standards to qualify to become members of the euro zone namely, budget deficit must not exceed 3\% of GDP and government debt must not exceed $60 \%$ of GDP. On average, debt for the euro zone-12 was approximately $60 \%$ of GDP until 2008 but rose to approximately $93 \%$ by before coming down slightly to $89 \%$ in 2017 (Table 1). Among the sample only Luxembourg did not breach the $60 \%$ threshold at any time in our sample period and Finland and Netherlands breached the threshold for brief periods (Table 1). The countries known as the PIIGS (Portugal, Ireland, Italy, Greece and Spain) have struggled with high debt levels. Greece and Italy had levels of debt to GDP over $100 \%$ for most of the period and Portugal breached the $60 \%$ threshold for most of the period with debt levels rising dramatically after the global financial crisis of 2008 (Table 1). Ireland and Spain started off strong with debt to GDP below the Maastricht threshold until 2009 and 2010 respectively, but suffered high debt for the rest of the period (Table 1). The rest of the countries, Austria, Belgium, France, and Germany breached the $60 \%$ threshold for most of the period, with the highest levels experienced by Belgium in this group (Table 1).

Deficit performance is slightly better with Luxembourg and Finland being the most successful in keeping deficits below 3\% of GDP for most of the period (Table 2). As with debt, the PIIGS struggle with deficits as well with Greece and Portugal being the worst performers (Table 2). Among the rest of the countries, France struggled with deficits for most of the period (Table 2). On average, deficits as a percentage of GDP stayed below the 3\% threshold until 2009 (following the global crisis) when it rose very high, reaching $8 \%$ in 2010 before declining and finally reaching below 3\% in 2015 (Table 2).

The European Commission introduced policies to address the various vulnerabilities and weaknesses experienced by member countries. The European Semester which is an annual cycle of coordination and surveillance of EU policies was implemented in 2010 and was revised since then, most recently in 2015 (Verdun and Zeitlin 2018). In 2011, Six-pack was introduced which included six regulations designed to reduce "macroeconomic imbalances and ensuring the viability of national finances through either preventive or corrective actions" (Delivorias 2014). This was followed by two-pack in 2013 which introduced "common budgetary timeline" and "enhanced surveillance" as a way to improve budgetary coordination (Delivorias 2014). All these measures were designed to improve EU governance and promote fiscal discipline. Overall improvements in fiscal indicators in the euro zone may be linked to these measures, although the debate about their benefit to member countries remains.

The relevant literature for analyzing monetary policy transmission is discussed in the following section. 
Table 1. Debt as a Percentage of GDP for Euro-12 Countries

\begin{tabular}{|c|c|c|c|c|c|c|c|c|c|c|c|c|c|c|c|c|}
\hline Country & 2002 & 2003 & 2004 & 2005 & 2006 & 2007 & 2008 & 2009 & 2010 & 2011 & 2012 & 2013 & 2014 & 2015 & 2016 & 2017 \\
\hline Austria & 59.8 & 59.9 & 59.8 & 64.1 & 64.2 & 62.5 & 66.0 & 78.1 & 80.8 & 80.5 & 80.9 & 80.6 & 83.1 & 83.5 & 82.6 & 77.7 \\
\hline Belgium & 102.7 & 99.8 & 95.7 & 94.1 & 90.6 & 86.8 & 91.3 & 99.4 & 99.7 & 102.6 & 104.3 & 105.3 & 107.0 & 106.1 & 106.0 & 103.4 \\
\hline Finland & 34.8 & 41.7 & 42.0 & 39.3 & 37.4 & 33.3 & 32.1 & 40.9 & 46.3 & 47.8 & 53.1 & 55.7 & 59.1 & 62.4 & 61.9 & 59.6 \\
\hline France & 60.0 & 64.1 & 64.9 & 66.0 & 63.5 & 63.5 & 67.5 & 79.4 & 81.5 & 84.0 & 87.9 & 90.6 & 92.8 & 93.3 & 93.9 & 94.0 \\
\hline Germany & 59.3 & 62.8 & 64.5 & 66.5 & 66.0 & 63.2 & 64.2 & 71.5 & 79.9 & 76.8 & 77.3 & 75.1 & 72.2 & 68.1 & 65.3 & 61.2 \\
\hline Greece & 102.0 & 99.6 & 101.6 & 106.0 & 102.6 & 102.3 & 108.7 & 126.2 & 143.6 & 167.6 & 154.3 & 170.1 & 171.2 & 170.5 & 175.1 & 173.7 \\
\hline Ireland & 29.2 & 28.1 & 27.7 & 25.9 & 23.5 & 23.4 & 38.6 & 58.1 & 85.7 & 105.1 & 111.1 & 109.7 & 96.7 & 73.7 & 70.1 & 66.6 \\
\hline Italy & 99.1 & 98.5 & 98.2 & 100.1 & 101.9 & 99.6 & 102.2 & 112.4 & 115.3 & 116.4 & 123.2 & 128.9 & 131.6 & 131.3 & 131.8 & 131.6 \\
\hline Luxembourg & 6.9 & 6.8 & 7.3 & 7.4 & 7.8 & 7.7 & 14.9 & 15.7 & 19.8 & 18.7 & 22.0 & 23.7 & 22.7 & 22.0 & 20.8 & 23.0 \\
\hline Netherlands & 48.1 & 49.2 & 49.5 & 48.9 & 44.4 & 42.0 & 52.5 & 53.3 & 56.1 & 58.6 & 62.2 & 66.2 & 67.0 & 63.9 & 61.1 & 56.2 \\
\hline Portugal & 54.3 & 57.9 & 61.7 & 67.2 & 69.0 & 68.3 & 71.2 & 82.4 & 94.9 & 102.4 & 112.5 & 114.2 & 112.0 & 114.7 & 118.7 & 120.9 \\
\hline Spain & 50.2 & 46.8 & 44.7 & 41.8 & 38.6 & 35.4 & 39.2 & 52.4 & 59.8 & 69.2 & 85.4 & 95.1 & 100.1 & 99.2 & 98.8 & 98.2 \\
\hline Euro-12 Av. & 58.9 & 59.6 & 59.8 & 60.6 & 59.1 & 57.3 & 62.4 & 72.5 & 80.3 & 85.8 & 89.5 & 92.9 & 93.0 & 90.7 & 90.5 & 88.9 \\
\hline
\end{tabular}

Notes: Data reported is a three-year moving average. Shaded cells indicate that the debt as a percentage of GDP is $60 \%$ or greater (meaning the Maastricht Treaty was breached).

Source: European Central Bank. 
Table 2. Budget Deficit as a Percentage of GDP for Euro-12 Countries

\begin{tabular}{|c|c|c|c|c|c|c|c|c|c|c|c|c|c|c|c|c|}
\hline Country & 2002 & 2003 & 2004 & 2005 & 2006 & 2007 & 2008 & 2009 & 2010 & 2011 & 2012 & 2013 & 2014 & 2015 & 2016 & 2017 \\
\hline Austria & -1.4 & -1.8 & -4.8 & -2.5 & -2.5 & -1.4 & -1.5 & -5.3 & -4.4 & -2.6 & -2.2 & -2.0 & -2.7 & -1.0 & -1.6 & -0.7 \\
\hline Belgium & 0.0 & -1.8 & -0.2 & -2.8 & 0.2 & 0.1 & -1.1 & -5.4 & -4.0 & -4.1 & -4.2 & -3.1 & -3.1 & -2.5 & -2.5 & -1.0 \\
\hline Finland & 4.1 & 2.4 & 2.2 & 2.6 & 3.9 & 5.1 & 4.2 & -2.5 & -2.6 & -1.0 & -2.2 & -2.6 & -3.2 & -2.8 & -1.8 & -0.6 \\
\hline France & -3.2 & -4.0 & -3.6 & -3.4 & -2.4 & -2.6 & -3.3 & -7.2 & -6.9 & -5.2 & -5.0 & -4.1 & -3.9 & -3.6 & -3.4 & -2.6 \\
\hline Germany & -3.9 & -4.2 & -3.7 & -3.4 & -1.7 & 0.2 & -0.2 & -3.2 & -4.2 & -1.0 & 0.0 & -0.1 & 0.5 & 0.8 & 1.0 & 1.3 \\
\hline Greece & -6.0 & -7.8 & -8.8 & -6.2 & -5.9 & -6.7 & -10.2 & -15.1 & -11.2 & -10.3 & -8.9 & -13.2 & -3.6 & -5.7 & 0.6 & 0.8 \\
\hline Ireland & -0.5 & 0.4 & 1.3 & 1.6 & 2.8 & 0.3 & -7.0 & -13.8 & -32.1 & -12.7 & -8.0 & -6.1 & -3.6 & -1.9 & -0.5 & -0.3 \\
\hline Italy & -3.0 & -3.3 & -3.5 & -4.1 & -3.5 & -1.5 & -2.6 & -5.2 & -4.2 & -3.7 & -2.9 & -2.9 & -3.0 & -2.6 & -2.5 & -2.3 \\
\hline Luxembourg & 2.4 & 0.2 & -1.3 & 0.1 & 1.9 & 4.2 & 3.3 & -0.7 & -0.7 & 0.5 & 0.3 & 1.0 & 1.3 & 1.4 & 1.6 & 1.5 \\
\hline Netherlands & -2.1 & -3.0 & -1.7 & -0.3 & 0.2 & 0.2 & 0.2 & -5.4 & -5.0 & -4.3 & -3.9 & -2.4 & -2.3 & -2.1 & 0.4 & 1.1 \\
\hline Portugal & -3.3 & -4.4 & -6.2 & -6.2 & -4.3 & -3.0 & -3.8 & -9.8 & -11.2 & -7.4 & -5.7 & -4.8 & -7.2 & -4.4 & -2.0 & -3.0 \\
\hline Spain & -0.4 & -0.4 & 0.0 & 1.2 & 2.2 & 1.9 & -4.4 & -11.0 & -9.4 & -9.6 & -10.5 & -7.0 & -6.0 & -5.3 & -4.5 & -3.1 \\
\hline Euro-12 Av. & -1.4 & -2.3 & -2.5 & -1.9 & -0.8 & -0.3 & -2.2 & -7.1 & -8.0 & -5.1 & -4.4 & -3.9 & -3.1 & -2.5 & -1.3 & -0.7 \\
\hline
\end{tabular}

Notes: Shaded cells indicate that the deficit as a percentage of GDP is 3\% or greater (meaning the Maastricht Treaty was breached).

Source: European Central Bank. 


\section{Relevant Literature}

There are many studies estimating monetary policy transmission mechanisms including Bernanke and Blinder (1992) and Kashyap and Stein (1995) for the U.S. and Hülsewig et al. (2004) for Germany. Others have conducted comparative analyses monetary policy transmission mechanisms in different countries such as Dedola and Lippi (2005) for France, Germany, Italy, UK, and U.S., and Gerlach and Smets (1995) for Canada, Italy, Germany, France, Japan, UK, and U.S. Monetary transmission in regions or economic and monetary unions has also been investigated such as Haug et al. (2005) on Australia and New Zealand for the possible effects of a currency union between the two countries and Buigut (2009, 2010) on Uganda and Kenya for the proposed East African Community.

One important strand of research compares the "similarity" of monetary transmission within countries of the European Monetary Union. Evidence of this before the introduction of the euro is mixed. Some scholars including Ehrmann (1998), Cecchetti (1999), Mihov (2001), Van Els et al. (2001), Clausen and Hayo (2002) find significant differences in the monetary transmission mechanism across countries. However, Kieler and Saarenheimo (1998), and Guiso et al. (1999) and Mojon and Peersman (2001) do not find significant variation in the transmission mechanism prior to the introduction of a single currency.

There are also monetary transmission studies after the introduction of the euro. Poghosyan and de Haan (2007) combine pre and post-euro data (1980-2006) to analyze monetary transmission in the euro zone. They find evidence that financial integration in the union was not yet complete. Barigozzi et al. (2014) finds that there are differences between more and less developed countries.

However, Anzuini and Levy (2007) find that not only is monetary tranmission similar between newer members of the euro zone, Hungary, Poland, and the Czech Republic, but it is also similar to more developed countries in the euro zone. Boivin et al. (2008) find heterogeneity in the monetary transmission mechanism among countries before the inception of the euro while the launch of the euro has brought greater homogeneity. They also conclude that the launch of the euro has resulted in a dampening of the effects of monetary shocks

The above studies shed light on monetary transmission in individual countries for the euro area. Our focus is on monetary transmission for the euro zone as a group. This is examined by Peersman and Smets (2001) who estimate euro area wide monetary transmission based on 'synthetic' euro area data from 1980 to 1998 (before the introduction of the euro). They find that an increase in the short-term interest rate (tight monetary policy) will lead to a decline in GDP and inflation. Also, they find that significantly more variation in output can be explained by monetary policy compared with inflation. We extend this analysis, by estimating monetary policy transmission in the euro zone since the introduction of the euro. The framework for our analysis is discussed in the following section. 


\section{Methodology}

We estimate monetary policy transmission through the bank lending channel for the euro zone-12 countries. "Kashyap and Stein (1994) trace the origins of thought on the bank lending channel back to Roosa (1951) and also highlight Blinder and Stiglitz's (1983) resurrection of the loanable funds theory and Bernanke and Blinder's (1988) extension of the IS-LM model" (Ireland, 2005, p. 5). As noted earlier, the bank lending channel relates changes in the short-term interest with bank lending and long-term interest which ultimately impacts output (Ireland 2005).

The standard empirical framework to estimate monetary transmission mechanism is through a vector autoregression (VAR). Most of the studies discussed earlier use VAR analysis ${ }^{1}$ which includes a system of variables that are endogenous and interdependent, although there could be exogenous variables as well. We estimate a panel VAR (pVAR) with quarterly data from 2002 to 2016 for the original twelve euro zone countries. A pVAR is similar in structure in that variables in a system are endogenous and interdependent (again, allowing for exogenous variables) but differs from a VAR because it also includes a cross sectional dimension. This allows for cross sectional heterogeneity which in practical terms indicates that it allows for country differences.

The pVAR is represented by the following equation:

$Y_{i t}=\Gamma_{1} Y_{i t-1}+\Gamma_{2} Y_{i t-2}+\cdots+\Gamma_{p-1} Y_{i t-p+1}+\Gamma_{p} Y_{i t-p}+\mathrm{A} X_{i t}+u_{i}+\varepsilon_{i t}$

where $Y_{i t}$ is a vector of endogenous variables, $X_{i t}$ is a vector of exogenous variables, $u_{i}$ is a vector of panel fixed effects, $\varepsilon_{i t}$ is a vector of idiosyncratic error terms and $\Gamma_{s}$ and $\mathrm{B}$ are matrices of parameters to be estimated.

The variables in our pVAR estimation are based on Hülsewig et al. (2004) for Germany which include output, inflation, short-term interest rate, bank loans, and long-term interest rates, so $Y_{i t}$ is a $(5 \mathrm{x} 1)$ vector of these variables. We contribute three variables that capture the role of fiscal indicators in monetary policy transmission which has, and continues, to be a challenge for the euro zone. To capture the importance of debt, we add a variable which is calculated as the deviation of debt as a percentage of GDP from the $60 \%$ threshold in the Maastricht Treaty. For deficits, we must account for both positive and negative balances as well as negative balances below and above the 3\% Maastricht Treaty threshold. Thus, we construct a variable by multiplying the fiscal balance as a percentage of GDP with a dummy variable that takes a value of 1 if the $3 \%$ threshold is breached and 0 otherwise. Finally, we hypothesize that if a country breaches both the debt and deficit threshold, it may have a bigger impact on economic variables. Thus, we include a dummy variable that takes on a value of 1 if both thresholds are breached and 0 if only one or neither of the thresholds has been breached. These

${ }^{1}$ Poghosyan and de Haan (2007) use vector error correction method (VECM) and Barigozzi et al. (2014) employ a structural dynamic factor model. 
three fiscal variables are exogenous in the VAR system, so $X_{i t}$ is a $(3 \times 1)$ vector including these variables.

After we determine the appropriate lag length using Schwarz criterion we estimate a pVAR. We then analyze the impulse responses and variance decomposition to shed light on monetary policy transmission in the euro zone. The order of the variables matters for these results. We follow Hülsewig et al. (2004) as described earlier (and the three variables related to fiscal vulnerability are exogenous to the system). The impulse response function captures the impact of a one-unit shock to monetary policy (short-term interest rate) on other variables. The variance decomposition shows the percentage of variation in each variable that can be explained by other variables in the system. We are interested in the effect of monetary policy as determined by changes in the short-term interest rate on output and inflation. Data and results are discussed in the following section.

\section{Data and Results}

We use quarterly data from 2002:Q1 to 2016:Q3 for euro zone-12 countries in our panel VAR estimation of monetary policy transmission. As noted earlier, the variables in our system (in this order) are: output, inflation, short-term interest rate, bank loans, and long-term interest rate. The three fiscal variables are exogenous to the system. We use the index of industrial production, IIP, as a proxy for output $(2010=100)$, the percentage change in the three-month average of the harmonized index of consumer prices $(2015=100)$ for inf, and the ECB marginal lending facility interest rate for short-term interest rate $(S T I R)$. If there are multiple interest rates in a quarter, we use an average for that period. Long-term interest rates (LTIR) are represented by monetary financial institutions (MFI) over-5 year maturity rates. For bank loans (loans) we use total outstanding end-of-period loan stocks from the MFI balance sheet. We construct debt as the deviation of debt as a percentage of GDP from the $60 \%$ threshold set by the Maastricht Treaty. For def we calculate the deviation of fiscal balance as a percentage of GDP from the $3 \%$ Maastricht Treaty threshold and multiply it by a dummy variable which takes on a value 1 if the deficit threshold is breached and 0 otherwise. Finally, we calculate a combination variable, debtdef, which is a dummy variable that takes a value of 1 if both thresholds are breached and 0 if either one or neither one of them have been breached. IIP and loans, are expressed in logarithmic form. Data for IIP is available from IMF, International Financial Statistics database and the rest are available from European Central Bank, statistical data warehouse.

Our sample contains macroeconomic variables that could be no stationary. We test for stationary using the Levin, Lin, and Chu test and the results are summarized in Table 3. Most variables are stationary except for loans. Although, the unit root test results show that one of the variables, loans, is no stationary we are still able to estimate a VAR (Sims 1980, Sims et al. 1990). 
Table 3. Unit Root Tests

\begin{tabular}{|l|c|c|}
\hline Variable & Test & P-value \\
\hline IIP & $-2.76^{*}$ & 0.00 \\
\hline Loans & -0.74 & 0.23 \\
\hline$\Delta$ Loans & $-9.01^{*}$ & 0.00 \\
\hline LTIR & $-2.23^{*}$ & 0.01 \\
\hline Inf & $-7.33^{*}$ & 0.00 \\
\hline STIR & $-2.73^{*}$ & 0.00 \\
\hline
\end{tabular}

Notes: Test statistics are reported for the Levin, Lin, and Chu test assuming a constant and using one lag. We report test statistics and p-values. The null hypothesis is that the series is no stationary.

*indicates rejection of the null hypothesis at $5 \%$ level of significance respectively.

The appropriate lag length is determined to be 2 lags based on the Schwarz criterion. Once we estimate the panel VAR, we can analyze impulse response functions and variance decomposition results. We first analyze the impulse responses which are graphed with 95\% confidence intervals in Figure 1.

As noted earlier, the bank lending channel for monetary policy transmission is based on the impact that tight monetary policy reduces bank lending and thus hurts output. Similar to the results for the U.S. (Bernanke and Blinder 1992) and Germany (Hülsewig et al. 2004), we find that higher short-term interest rates lead to a decline in bank loans (Figure 1). However, the small decline suggests that bank lending is a weak channel for monetary policy transmission, at least for the euro zone countries. This is likely related to the sample period which includes the global financial crisis and the PIIGS crisis that led to significant non-traditional monetary policy (quantitative easing) programs. As Ciccarelli et al. (2013) concludes, "the bank-lending channel has been to a large extent neutralized" by ECB's "non-standard monetary policy interventions" (p. 463).

We turn now to analyzing the impact of the monetary policy on output and inflation and compare our results on output and inflation to Peersman and Smets (2001) that shed light on monetary policy transmission for the 'synthetic' euro area. We expect that a positive shock to short term interest rates would reduce both output and inflation. Like Peersman and Smets (2001) we find that after the first quarter, tight monetary policy reduces output (Figure 1). Unexpectedly, we find a positive relation between a shock to short-term interest rates and inflation (Figure 1). For a significant portion of the sample period, countries in the euro zone (and elsewhere) were experiencing economic distress. This helps explain why lowering interest rates did not lead to higher inflation.

We also examine variance decomposition results, reported in Table 4. Similar to Peersman and Smets (2001) we see an increasing amount of variation due to short-term interest rates in output and inflation over the two-year period. In the case of output, the variation attributed to short-term interest rises from about $5 \%$ in the last quarter of the first year to a little over $6 \%$ by the end of the second year (Table 4). For prices, the variation explained by short term interest rates doubles from a little above $5 \%$ at the end of the first year to close to $10 \%$ by the end of the second year (Table 4). The comparable numbers for Peersman and Smets (2001) are $13 \%$ to $28 \%$ for output and $3 \%$ to $9 \%$ for prices (Table 1, p. 13). The much smaller impact on output in our results is not surprising given that standard 
monetary policy tools proved ineffective in the face of the severe global financial crisis. It is also possible that the smaller impact is related to the inclusion of disparate countries that were facing differential challenges.

Figure 1. Impulse Responses of Variables to a One-Unit Shock in STIR (Monetary Policy)
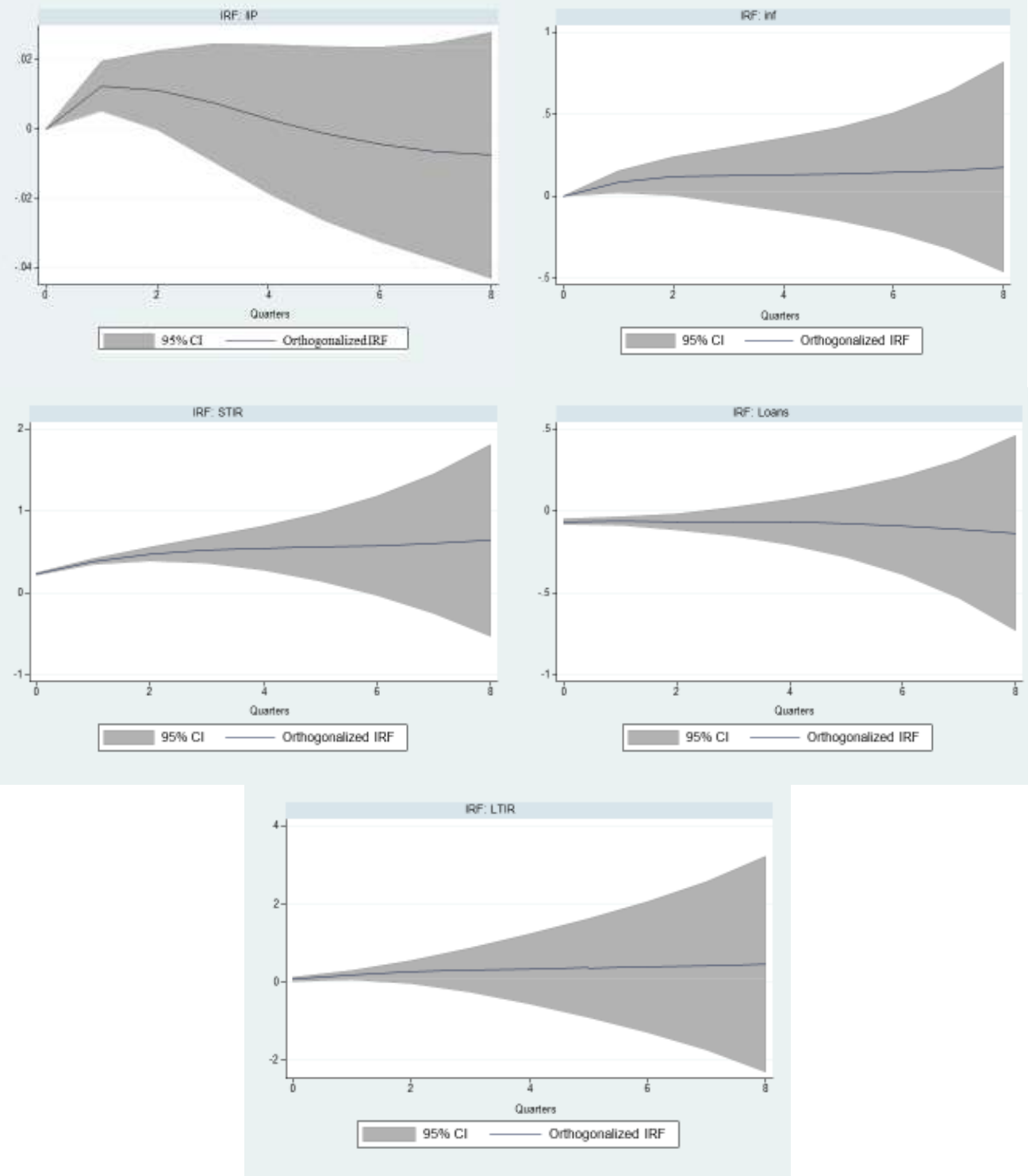
Table 4. Forecast-Error Variance Decomposition of Output and Prices

\begin{tabular}{|c|c|c|c|c|c|}
\hline Period & IIP & Inf & \multicolumn{1}{l|}{ STIR } & Loans & LTIR \\
\hline \multicolumn{5}{|c|}{ Variance Decomposition of IIP } \\
\hline Q 1 & 100 & 0.00 & 0.00 & 0.00 & 0.00 \\
\hline Q 2 & 97.17 & 0.10 & 2.74 & $\sim 0.00$ & $\sim 0.00$ \\
\hline Q 3 & 95.28 & 0.18 & 4.52 & $\sim 0.00$ & 0.02 \\
\hline Q 4 & 94.02 & 0.56 & 5.30 & $\sim 0.00$ & 0.12 \\
\hline Q 5 & 93.40 & 0.84 & 5.39 & $\sim 0.00$ & 0.37 \\
\hline Q 6 & 92.95 & 0.91 & 5.39 & 0.01 & 0.75 \\
\hline Q 7 & 92.23 & 0.91 & 5.66 & 0.01 & 1.20 \\
\hline Q 8 & 91.06 & 1.07 & 6.23 & 0.01 & 1.63 \\
\hline Variance Decomposition of Prices & \multicolumn{5}{|l}{} \\
\hline Q 1 & 1.22 & 98.78 & 0 & 0 & 0 \\
\hline Q 2 & 8.22 & 85.73 & 1.24 & 4.45 & 0.37 \\
\hline Q 3 & 8.06 & 82.66 & 3.27 & 5.29 & 0.73 \\
\hline Q 4 & 7.52 & 77.95 & 5.16 & 8.40 & 0.98 \\
\hline Q 5 & 8.14 & 73.23 & 6.70 & 10.86 & 1.08 \\
\hline Q 6 & 8.71 & 68.09 & 7.92 & 14.20 & 1.08 \\
\hline Q 7 & 9.68 & 62.81 & 8.90 & 17.58 & 1.02 \\
\hline Q 8 & 10.55 & 57.46 & 9.75 & 21.31 & 0.93 \\
\hline
\end{tabular}

Notes: The forecast variance decomposition are based on the same order of the variables in the panel VAR as the impulse reponse functions. We report results eight quarters. In some cases, the sum of the variance decomposition exceeds $100 \%$ due to rounding off numbers.

We turn now to examining the role of debt and deficits in monetary policy transmission. These results are reported in Table 5. None of the fiscal indicators are statistically significant determinants of short-term interest rates and bank loans (Table 5) which suggests that monetary policy and bank lending are unaffected by rising debt and deficit levels. While debt does not have a statistically significant impact on any of the variables in the system, it is "important" for output (Table 5). This indicates that high debt levels hurt economic growth. The deficit variable has a statistically significant negative impact on prices (Table 5). As fiscal balance as a percentage of GDP falls (meaning as the deficit increases), prices rise. Unexpectedly, breaching the fiscal thresholds lowers the long-term interest rate (Table 5). The combination variable has a statistically significant impact on IIP (Table 5) which indicates that vulnerability in both fiscal indicators (meaning that debt and deficit exceed the Maastricht Treaty threshold) hurts output. This is expected as breaching the threshold for debt and deficits puts even more pressure on countries struggling with the global crisis. This was likely exacerbated by various ECB policies to impose greater fiscal discipline discussed earlier.

We conclude with the broader implications of our results in the following section. 
Table 5. Impact of Fiscal Indicators on Endogenous Variables in the Panel VAR

\begin{tabular}{|c|c|c|c|c|c|c|}
\hline & \multicolumn{2}{|c|}{ Debt } & \multicolumn{2}{c|}{ Def } & \multicolumn{2}{c|}{ Debtdef } \\
\hline & Coefficient & p-value & Coefficient & p-value & Coefficient & p-value \\
\hline IIP & $-0.0008^{+}$ & 0.1550 & 0.0005 & 0.3960 & $-0.0318^{*}$ & 0.0000 \\
\hline Inf & 0.0061 & 0.2835 & $-0.0386^{* *}$ & 0.0810 & -0.0061 & 0.4700 \\
\hline STIR & -0.0025 & 0.2375 & -0.0008 & 0.4630 & -0.0168 & 0.2645 \\
\hline Loans & -0.0006 & 0.4170 & -0.0011 & 0.4500 & -0.0052 & 0.415 \\
\hline LTIR & 0.0016 & 0.4550 & -0.0181 & 0.3190 & $-0.1055^{* *}$ & 0.0710 \\
\hline
\end{tabular}

Notes: the coefficients for the three fiscal variables (debt, def, and debtdef) and their p-values are reported for the pVAR.

"and ${ }^{* *}$ indicates the variable is statistically significant at 5\% and $10 \%$ level of significance respectively. ${ }^{+}$indicates that while the variable is not statistically significant at usual levels of significance, the variable is important.

\section{Conclusion}

In this paper we analyze monetary policy transmission via the bank lending channel in euro zone-12 countries. Using quarterly data from 2002 to 2016 we estimate a panel VAR with output, prices, short-term interest rate, bank loans, and long-term interest rate. We also include debt and deficit indicators to capture the role of fiscal vulnerability on output and prices.

We find evidence that bank lending is an appropriate, albeit a weak, mechanism for monetary policy transmission in the euro zone. As noted earlier, this could be linked to the period under study that included a global crisis and excessive use of non-standard monetary policy. Bank lending may become a more effective channel of monetary policy transmission in the future with the expected conclusion of ECB's quantitative easing program at the end of $2018 .{ }^{1}$

Our empirical analysis reveals that a positive shock to in short-term interest rates has a negative impact on output, which suggests that loose monetary policy promotes growth. Unexpectedly, a positive shock in short-term interest rates has a small but positive impact on inflation. This trend is likely related to the breakdown of the link between monetary policy and inflation due to the severe global crisis that impacted the euro zone countries dramatically.

The trajectory of the impact of monetary policy on output is similar to that found by Peersman and Smets (2001) for the 'synthetic' euro area. However, the variation in output due to the monetary policy variable is much smaller in our sample than that observed by Peersman and Smets (2001). The global crisis that weakened the effectiveness of monetary policy is one explanation. Another is the differential impact of monetary policy on different countries facing unique challenges. For example, the PIIGS had far greater challenges than some of the other countries in our sample.

\footnotetext{
${ }^{1}$ The 2015 quantitative easing program launched by the ECB is expected to be halted by December 2018. This was announced by President of ECB, Mario Draghi, in a press conference on July 26, 2018 (https://www.ecb.europa.eu/press/pressconf/2018/html/ecb.is180726.en.html).
} 
In addition, we found that debt and deficits affect monetary policy transmission mechanism. High debt and deficits are linked with declining output. Fiscal vulnerability may put pressure on an economy and thus hurt output. It is also the case that a weaker economy strains the budget and causes rising deficits and debt. We believe that the link between fiscal vulnerability and output works both ways where declining output raises deficits and debt and when the Maastricht Treaty thresholds are breached it puts further pressure on output. Based on our empirical analysis we conclude that, for the Eurozone countries, if both the debt and the deficit thresholds established by the Maastricht Treaty are breached, this has a negative effect on output.

The differential results compared to earlier analysis and the impact of fiscal vulnerability suggest that the euro zone is at best, operating as only a partially integrated unit. This supports the evidence of some authors such as Poghosyan and de Haan (2007) and Barigozzi, et al. (2014) that there is asymmetry in monetary policy transmission in the euro zone. We offer another reason why there may be asymmetric effects, high deficits and debt burdens. It remains to be seen whether measures to impose further fiscal discipline to ensure that countries meet the Maastricht Treaty thresholds for debt and budget deficits lead to greater homogeneity in how monetary policy affects output.

\section{References}

Angeloni I, Ehrmann M (October 2003) Monetary Transmission in the Euro Area: Early Evidence. Economic Policy, CEPR, CES, MSH, 18(37): 469-501.

Angeloni I, Kashyap A, Mojon B, Terlizzese D (January 2002) Monetary Transmission in the Euro Area: Where do we Stand? European Central Bank Working Paper, 114: 383-412.

Anzuini A, Levy A (2007) Monetary Policy Shocks in the New EU Members: A VAR Approach. Applied Economics, 39(9): 1147-61.

Barigozzi M, Conti AM, Luciani M (2014) Do Euro Area Countries Respond Asymmetrically to the Common Monetary Policy. Oxford Bulletin of Economics and Statistics 76(5): 693-714.

Bernanke, Blinder (September 1992) The Federal Funds Rate and the Channels of Monetary Transmission. American Economic Review 82(4): 901-921.

Boivin J, Giannoni MP, Mojon B (2008) How has the Euro changed the Monetary Transmission Mechanism? NBER Macroeconomics Annual 23(1): 77-125. University of Chicago Press.

Buigut S (2009) Monetary Policy Transmission Mechanism: Implications for the proposed East African Community (EAC) Monetary Union. CSAE Oxford Conference Economic Development in Africa. Retrieved from https://bit.ly/2pqQ1qB.

Buigut S (2010) Is there a Bank Lending Channel of Monetary Policy in Kenya. International Research Journal of Finance and Economics, 45(August 2010): 183-192.

Cecchetti S (1999) Legal Structure, Financial Structure and the Monetary Policy Transmission Mechanism. NBER Working paper \#7151. 
Ciccarelli M, Maddaloni A, Peydró JL (2013) Heterogeneous Transmission Mechanism: Monetary Policy and Financial Fragility in the Eurozone. Economic Policy 28(75): 459-512. doi=10.1111/1468-0327.12015.

Clausen V, Hayo B (2002) Asymmetric Monetary Policy Effects in EMU. ZEI Working Paper, no. B 04-2002.Retrieved from https://bit.ly/2MLerV7.

Dedola L, Lippi F (2005) The Monetary Transmission Mechanism: Evidence from the Industries of Five OECD Countries. European Economic Review, 49(6): 1543-69.

Delivorias A (2014 December) Review of the 'Six-pack' and 'Two-pack. European Parliamentary Research Service EN PE 542.182.

Ehrmann (1998) Will EMU Generate Asymmetry? Comparing Monetary Policy Transmission across European Countries. EUI Working Paper, ECO No. 98/28.

Gerlach S, Smets F (1995) The Monetary Transmission Mechanism: Evidence from the G-7 Countries. BIS Working Paper 26. SSRN: http://ssrn.com/abstract=868427. doi=/10.2139/ssrn.868427.

Guiso L, Kashyap A, Panetta F, Terlizzese D (1999) Will a Common European Monetary Policy have Asymmetric Effects? Federal Reserve Bank of Chicago Economic Perspective 23(4): 56-75

Haug AA, Karagedikli Ö, Ranchold S (2005) Monetary Policy Transmission Mechanisms and Currency Unions: A Vector Error Correction Approach to a Trans-Tasman Currency Union. Journal of Policy Modeling 27(1): 55-74.

Hülsewig O, Winker P, Worms A (2004) Bank Lending in the Transmission of Monetary Policy: A VECM Analysis for Germany. Journal of Economics and Statistics 224(5): 511-529.

Ireland P (2005 November) The Monetary Transmission Mechanism. Federal Reserve Bank of Boston Working Papers 06-1.

Kashyap AK, Stein JC (1995) The Impact of Monetary Policy on Bank Balance Sheets. Carnegie-Rochester Conference Series on Public Policy 42(1): 151-195.

Kieler M, Saarenheimo T (1998) Differences in Monetary Policy Transmission? A Case not Closed. European Commission Economic Papers 132: 1-35.

Mihov I (2001) Monetary Policy Implementation and the Transmission in the European Monetary Union. Economic Policy 33(1): 369-402.

Mojon B, Peersman G (2001) A VAR Description of the Effects of Monetary Policy in the Individual Countries of the Euro Area. European Central Bank Working Paper 92: 56-74.

Peersman G, Smets F (2001 December) Monetary Policy Transmission Mechanism in the Euro Area: More Evidence from VAR Analysis. European Central Bank Working Paper 91: 36-55.

Poghosyan T, Haan DJ (2007) Interest Rate Linkages in EMU Countries: A Rolling Threshold Vector Error-Correction Approach. CESifo Working Paper 2060. SSRN: http://ssrn. com/abstract=1002868.

Sims C (1980) Macroeconomics and Reality. Econometrica 48(1): 1-48.

Sims C, Stock J,Watson M (1990) Inference in Linear Time Series Models with some Unit Roots. Econometrica 58(1): 113-44.

Van Els P, Locarno A, Morgan J, Villetelle JP (2001) Monetary Policy Transmission in the Euro Area: What do Aggregate and National Structural Models tell us? European Central Bank Working Paper Series 94: 91-106.

Verdun A, Zeitlin J (2018) Introduction: The European Semester as a New Architecture of EU Socioeconomic Governance in Theory and Practice. Journal of European Public Policy 25(2): 137-148. DOI=10.1080/13501763.2017.1363807. 